\title{
Liver Fibrosis: Causes and Methods of Assessment, A Review
}

\author{
ALI ERFANI KARIMZADEH TOOSI \\ ${ }^{1}$ Shahid Beheshti University Hospital, Guilan University of Medical Sciences, Gilan, Iran
}

\begin{abstract}
Hepatic fibrogenesis is the final result of injury to the liver. Fibrosis could lead to hepatic dysfunction, important in the pathogenesis of other chronic problems. Therefore, understanding the mechanism, accurate diagnosis and staging of it in early stages accelerates the treatment and reduces the prevalence of chirrosis. Treatment strategies of liver problems and detction methods depend on the amount and progression of liver fibrosis and the rate of cirrhosis development. Traditionally the invasive method, liver biopsy, is reference standard to follow progression and stage of fibrosis. However, during the past decade, progressive development of novel non-invasive methodologies has challenged the invasive method. Non-invasive methods have been initially introduced for chronic hepatitis $\mathrm{C}$ with increasing use in other chronic liver diseases. The need for liver biopsy has nowadays decreased significantly as a result of these methodologies. Most of the new non-invasive methods depend on either 'biological' or 'physical' approaches.

In this review, starting from the mechanism of fibrogenesis, the current knowledge about diagnosis, treatment strategies and different methods for its evaluation is discussed. This is followed by a conclusion on what is expected to be known in this field during the future research.
\end{abstract}

Key words: Liver biopsy, FibroScan ${ }^{\circledR}$, Fibrosis, Fibrosis mechanism, Fibrotest.

\section{INTRODUCTION}

Hepatic fibrogenesis is the final common result of injury to the liver, a critical factor leading to hepatic dysfunction and it may be important in the pathogenesis of other chronic problems such as portal hypertension [1] and biliary cirrhosis [2, 3]. An accurate assessment of fibrosis degree is, therefore, important clinically. Examination of hepatic histopathology has been considered to be the gold standard method for assessment of fibrosis for many years. However, due to its invasive nature, liver biopsy is not favored by patients or physicians on many occasions. Thus, a specific search for alternative approaches to measure liver fibrosis is an attractive area of investigation [4, 5]. Most of the new non-invasive methods depend on either 'biological' or 'physical' approaches. In the biological methods, the level of some biomarkers in serum is indication of liver damage. On the other hand, the basis of physical approach is liver stiffness measured by ultrasonic method, transient elastography (TE).

\section{MECHANISMS OF HEPATIC FIBROGENESIS}

A number of liver and other diseases as well as side effects of some drugs lead to liver fibrosis. Significant improvement in diagnosis and treatment of chronic liver disease has resulted in more interest in understanding the mechanism of fibrogenesis in the liver [7]. The occurrence of fibrosis is through integrated signaling networks that regulate the deposition of extracellular matrix. The activation of hepatic stellate cells (HSCs) is due to this cascade of responses. As a result, the HSCs are driven into a myofibroblast-like phenotype that is contractile, proliferative and fibrogenic. Liver fibrogenic cells are a heterogeneous population of cells including $\alpha$-smooth muscle actin positive myofibroblasts (MFs). They are highly proliferative and contractile with ability to promote fibrogenesis. They possess multiple phenotypic responses to injury including deposition of extracellular matrix (ECM) components and collagen to encapsulate injury. On the other hand, they promot synthesis of growth factor which promotes fibrogenesis. This is followed by chronic inflammatory response and neo-angiogenesis [7].

It is known that sustained fibrogenesis could ultimately lead to cirrhosis. Liver cirrhosis is characterized by a distortion of the liver parenchyma and vascular architecture [8]. The exact mechanism of fibrogenesis is complicated covering a wide range of cellular and molecular events. Therefore, development of targeted therapies to inhibit of reverse fibrogenesis is the aim of many researchs in this area. It has been found that MFs are also differentiated from bone marrow-derived 
stem cells [8]. Using a cross talk mechanism with hepatic progenitor and tumour cells, MFs may modulate the immune responses to hepatocellular carcinomas and metastatic cancers.

As a widely accepted fact, liver fibrosis is a risk factor for hepatoma and activated hepatic stellate cells (HSCs) play a critical role in progression of hepatoma. Although HSCs are important in liver fibrosis formation, their interaction with tumor cells is unclear. It has been hypothesized that HSCs could increase the epithelial-mesenchymal transition (EMT) ability of hepatoma cells. To elucidate the effect of HSCs on hepatoma cells, HSC-T6 has been co-cultured with hepatoma cell line (ML1). They concluded that HSCs can secrete collagen type I to trigger hepatoma cells and subsequently enhance tumor metastasis [9]. The presence of HSCs around tumors and its microenvironment has been reported in a number of researches and case studies [9-12]. It has been reported that the conditioned medium of hepatocellular carcinoma cell can trigger activation of HSCs, proliferation, and cell migration [13]. Therefore, tumors can stimulate HSCs to form stoma inducing the growth of tumor.

The first response of liver to different chronic insults is, usually, developing fibrosis. Acute and chronic liver injuries are accompanied by prominently increased expression of proinflammatory and profibrogenic mediators and their receptors. It is known that $\mathrm{N}$-glycosylated transmembrane proteins generally form these types of cytokine receptors [14].

The complicated process of cell migration requires a precise regulation and integration of multiple signaling pathways. During the whole process, ECM serves as the molecular scaffold for cell adhesion and migration. On the other hand, the cell surface proteins integrins and ECM are also functionally interconnected developing complex signaling pathways.

Although acute injury will activate the mechanistic pathway of fibrogenesis [15], the sustained signals associated with chronic liver disease caused by infection, co-infection [16], drugs, metabolic disorders, or immune attack are required for significant fibrosis to accumulate.

It has been expressed that any type of liver injury is associated with angiogenesis, sinusoidal remodeling, and expansion of stellate cell [8]. Therefore, mediators known for angiogenesis are also relevant in understanding hepatic fibrosis. These include platelet-derived growth factor
(PDGF), vascular endothelial growth factor (VEGF), and their cognate receptors. Besides, vasoactive mediators such as nitric oxide and carbon monoxide are also involved in this mechanism. In heavy smokers suffering from hepatitis $\mathrm{C}$, increased VEGF concentrations could be an important contributer to accelerated progression of fibrosis [17].

\section{PREVENTING AND TREATMENT OF LIVER FIBROSIS}

Since N-glycosylation of cell surface proteins cytokine receptors, integrins, and cadherins is affected by GnT-V [14], knockdown of GnT-V could inhibit cell migration. N-acetyl glucosaminyltransferase $\mathrm{V}(\mathrm{GnT}-\mathrm{V})$ may provide a feasible and promising therapeutic target in preventing liver fibrosis [18]. By inducing liver fibrosis in mouse, Liu et al. [18] observed significant increase of hepatic GnT-V fibrogenesis as well as upregulations of GnT-V in the activated HSCs. They found that knocking down the hepatic GnT-V expression led to reduced expression of GnT-V in fibrotic liver. They concluded that GnT-V is implicated in liver fibrosis, and, therefore, blocking GnT-V could be a feasible and promising approach to treat and prevent liver fibrosis. Although it is known that altered expression of GnT-V could modulate multiple cytokine signaling pathways leading to tumor invasion and metastasis, its role in the development of liver fibrosis is still contravenial.

Myofibroblastic transdifferentiation (MTD) is reported as the key event during liver fibrogenesis, and research in the past few years has identified important mediators and molecular mechanisms responsible for MTD of hepatic stellate cells (HSCs). There is a regulatory mechanism between differenttiation of adipocytes and that of HSC, and the shift from adipogenic to myogenic or neuronal phenotype characterizes HSC MTD [19]. The main event of this shift is a loss of expression of the master adipogenic regulator peroxisome proliferator activated receptor $\gamma(\mathrm{PPAR} \gamma)$. Restored expression of PPAR $\gamma$ and/or other adipogenic transcription genes can reverse myofibroblastic HSCs to differentiated cells. The expression of adipogenic transcription factors has been shown to be essential for the maintenance of HSC quiescence in vitro [20-22]. Wnt signal pathway in vertebrate is a homologous gene and the translated proteins could participate in the regulation of cell proliferation, cell polarity and cell differentiation. In human fibrosing diseases, 
such as pulmonary fibrosis, renal fibrosis, and liver fibrosis Wnt signaling plays a central role. Therefore, it is suggested that blocking the canonical Wnt signal pathway with the co-receptor antagonist Dickkopf-1 (DKK1) could block these epigenetic repressions and restores the gene PPAR $\gamma$ expression and HSC differentiation. This can be regarded as novel therapeutic targets for liver fibrosis and liver regeneration.

Triggers of epithelial-mesenchymal transition (EMT) could induce pathological problems such as organ fibrosis and tumor metastasis [23, 24]. It has been found that collagen I stimulates EMT through increased expression of some transcription factors [25-27]. These factors alter expression of epithelial and mesenchymal markers causing initiation of EMT and stimulation of cell migration.

Integrin-linked kinase (ILK) is an ubiquitously expressed serine/threonine protein kinase implicated in development, progression and metastasis of cancer [28]. The role of ILK in glioma cell invasion and migration has been characterized with concluding remark that ILK could be regarded as a potential for therapeutic interference.

Regulation of EMT and ILK signaling pathways plays an important role in tumor progression [29]. Xiong et al. found evidences to demonstrate that EMT was implicated in metastasis of bladder cancer. They have suggested that ribonuclease inhibitor (RI) could suppress development of cancer and prevent metastasis of bladder through regulating EMT and ILK signaling pathway.

The central and determinant role of ILK in EMT and metastasis has been demonstrated in the case of colorectal cancer, CRC [30]. ILK and EMT signaling pathways could open ways for novel therapeutic opportunities to treat cancers including CRC.

\section{CAUSES OF LIVER FIBROSIS}

Liver problems are among the most causes of death due to alcohol abuse in many countries. On the other hand, nonalcoholic fatty liver disease (NAFLD) is a common hepatic abnormality in the Western world, and progresses to cirrhosis and hepatocellular carcinoma in a significant portion of cases [31].

It has been estimated that in about $20-30 \%$ of patients suffering from chronic hepatitis $\mathrm{C}$ cirrhosis develops in almost 20 years. The virus causing the disease (HCV) possesses some certain proteins, including core and NS5A that induce derangement of lipid metabolism or alter signal transduction of infected hepatocytes which leads to the production of reactive oxygen radicals and profibrogenic mediators, in particular TGF-beta1 [33]. The effect of telaprevir-based antiviral regimens on improving liver health in patients infected $\mathrm{HCV}$ has been studied [33]. In that retrospective study, 1208 patients treated with a telaprevir-based regimen were included. The base of grouping patients was their baseline Metavir score (F0-F1, F2 and F3-F4). The results obtained from non-invasive biomarker tests, FibroTest, APRI, FIB-4 and Forns' Score, were then monitored before and after $\mathrm{HCV}$ treatment. It was concluded that attaining treatment with telaprevir-based regimen led to significant improvements in liver health as determined by four biomarker examinations [34, 35].

Liver fibrosis also occurs in other liver diseases including autoimmune and cholestatic liver diseases [36]. It is known that the mechanism of pathogenesis primary biliary cirrhosis, a cholestatic liver disease, is different from other chronic liver diseases. Portal fibroblasts located in the connective tissue surrounding bile ducts are somehow different from hepatic stellate cells regarding an appropriate response to the profibrogenic and mitogenic stimuli and expression of marker proteins.

On the other hand, many liver diseases originated from various causes in children and younger patients could become complicated by development of liver fibrosis and progression to cirrhosis [37]. In the case of paediatric liver disease, too, liver fibrosis has different histopathological patterns and their management depends on the stage of liver fibrosis.

In addition to modification of many liver functions, among the most important consequences of fibrosis in liver is portal hypertension. This abnormal condition results from an increased intrahepatic resistance and increased hepatic and portal arterial blood flow. The various changes in fibrotic and angio-architecture of liver tissue cause increased intrahepatic resistance [38]. On the other hand, the progressive failure of one of the detoxification mechanisms of liver together with toxic substances from the splanchnic circulation and end-products of bacterial functions lead to a systemic pro-inflammatory state with further accelerating disease progression. 


\section{ASSESSMENT OF LIVER FIBROSIS}

Despite its invasive character, liver biopsy is the most common and highly recommended 'reference standard' for diagnosis and staging of hepatic fibrosis. However, the progressive development of new methods and the need for a non-invasive method for accurate assessment of fibrosis has purposed the use of two alternative strategies to biopsy, i.e. 'biological' or 'physical' approaches. Biochemical markers of fibrosis in the serum could be tested and compared with the results of biopsy. On the other hand, transient elastography (TE, FibroScan $\left.{ }^{\circledR}\right)$ is a new physical method which non-invasively could assess and represent the state of hepatic fibrosis.

$\mathrm{TE}$ is a rapid and non-invasive technique that can easily be performed at the bedside resulting in immediate outcomes with highly reasonable reproducibility. This novel non-invasive method has been designed for assessment of hepatic fibrosis in patients with chronic liver diseases [39]. However, its validity could highly be increased if combined with other no-invasive devices including serum markers. This technique has considerably minimized the need for the invasive liver biopsy in today's diagnostic strategies. It has been found that TE is a reliable method for early detection of cirrhosis having a prognostic value as well. It is also a fast method that is highly accepted both by specialist and the patients. The accuracy of transient elastography for diagnosis and staging of fibrosis in those suffering from alcoholic liver disease has been compared to liver biopsy. In this study with 330 participants it has been found that sensitivity and specificity of transient elastography were 0.95 and 0.71 with LR+ 3.3 and LR- 0.07 . The study has concluded that transient elastography could be a reliable and useful physical method to be used as an alternative liver biopsy [39].

A review in 2011 has discussed the advantages as well as inconveniences of both biological and physical non-invasive methods in comparison with liver biopsy for the management of patients with chronic liver diseases [4]. During a 5 years research project, 1457 patients with chronic hepatitis $\mathrm{C}$, liver stiffness and fibrosis were assessed by non-invasive methods including FibroTest, the aspartate aminotransferase to platelet ratio index (FIB-4) and compared to liver biopsy samples. They reported that 77 patients had died and 16 patients had undergone liver transplantation during 5 years. It was also found that $91.7 \%$ had survived.
It was concluded that noninvasive tests for liver fibrosis, FibroTest can predict 5-year survival of patients with chronic hepatitis $\mathrm{C}$. These tools might help physicians determine prognosis at earlier stages and discuss specific treatments, such as liver transplantation [40].

Non-invasive methods of investigating fibrosis have also been used in the case of hepatitis $\mathrm{C}$ patients by other groups of investigators [41]. The accuracy of aspartate aminotransferase-to-platelet ratio index (APRI) in predicting fibrosis has been examined in a group of $\mathrm{HCV}$ infected patients and HCV/human immunodeficiency virus (HIV) coinfected individuals. The study was performed to find out significant fibrosis, severe fibrosis, and cirrhosis stages in patients [42]. They found that for severe fibrosis, a threshold of 1.0 was $61 \%$ sensitive and $64 \%$ specific, while for cirrhosis, a threshold of 1.0 was $76 \%$ sensitive and $72 \%$ specific. It was concluded that APRI can identify hepatitis C-related fibrosis with a moderate degree of accuracy. A more recent study has also evaluated significant fibrosis (SF) and cirrhosis in patients with chronic HCV [43]. In this 2014 study, platelet count, ALT, AST, AST to ALT Ratio, AST to Platelet Ratio Index (APRI), Forns index, FIB-4 and Age Platelet Index were investigated from the history of $202 \mathrm{HCV}$ patients who had undergone liver biopsy. The study concluded that SF and cirrhosis could be predicted with accuracy using fibrosis index which potentially decrease the need for liver biopsy in $76 \%$ and $83 \%$ of patients.

The validity of APRI to-platelet ratio index and FIB-4, an index from serum fibrosis markers (ALT, AST, and platelets plus patient age) for staging liver disease has been studied [44]. In that study, 2372 liver biopsies were identified from $\mathrm{HCV}$-infected patients together with laboratory values for inputing APRI and FIB-4. They reported that FIB-4 was sufficient at differentiating 5 stages of chronic HCV infection. They, therefore, announced it useful in screening patients who need biopsy and therapy, for monitoring patients with less advanced disease, and for longitudinal studies.

Developing an appropriate treatment plan for patients with various liver related problems, such as patients infected with HCV and those on chronic hemodialysis (HD), is highly determined by extent of fibrosis. Therefore, assessment of liver fibrosis in such cases could be one of the primary important steps. In such cases, the use of non-invasive methods for measuring fibrosis is always preferred by most specialists. In this regard, alternations in 
standard laboratory tests (AST, ALT, yGT, cholesterol and platelet count) and indirect serum fibrosis markers: AST-to-platelet ratio index (APRI), FIB-4 and Forns index, have been reported in chronically HCV-infected patients with and without antiviral treatment [45]. The study concluded that simple indices including APRI and FIB-4 were useful in monitoring for liver fibrosis rate after antiviral treatment in patients on maintenance HD infected by HCV and can be used as non-invasive methods for staging liver fibrosis progression.

In a systematic review by Shaheen and Myers [46], the performance of the APRI in hepatitis C virus (HCV)-infected patients was investigated. Based on a random meta-analysis, it was concluded that APRI accuracy was not affected by the prevalence of advanced fibrosis, or study and biopsy quality. On the other hand, in the cases of cirrhosis, the accuracy was greater in studies including $\mathrm{HCV}$ and HIV/HCV-co-infected patients.

A more recent work has systematically reviewed practical performance of APRI and Fibrosis 4 index (FIB-4) in hepatitis B virus (HBV) infection of adults. The diagnostic accuracy of APRI and FIB-4 for significant fibrosis, advanced fibrosis, and cirrhosis was investigated in a systematic review [47]. They included 16 articles of APRI only, 21 articles of APRI and FIB-4 and two articles of FIB-4 for detecting different levels of liver fibrosis. The results of a meta-analysis indicated that APRI and FIB-4 can identify hepatitis B-related fibrosis with a moderate sensitivity and accuracy.

The frequency, amplitude, disease activities, and associated factors of ALT and/or AST flares were assessed in 47 Asian patients with CHB [48]. The results from their study showed that ALT flare was not associated with baseline ALT level, fibrosis stage, inflammation grade, hepatitis B virus (HBV) DNA load, HBeAg status, HBV genotype, HBV precore and basal core promoter mutations. This was an attempt towards using non-invasive methods for diagnosis and following the progress of liver fibrosis.

Many disadvantages of significant limitations of liver biopsy have been partly overcome using noninvasive biomarkers for prediction of fibrogenesis in HBV infected patients with hepatitis B virus [49]. The systematic review was based on the assessment of the effectiveness and accuracy of these biomarkers for predicting HBV-related fibrosis. They reported that the heterogeneity of FIB-4 and FibroTest were not statistically significant. The heterogeneity of APRI for detecting significant fibrosis was affected by median age, while for cirrhosis it was affected by etiology. It was, therefore, concluded that FibroTest had excellent diagnostic accuracy for identification of HBV-related significant fibrosis and cirrhosis.

Assuming that liver biopsy is not only an invasive and expensive method, but it is also an imperfect gold standard, the relative accuracy of two widely used non-invasive techniques, Fibro Test ${ }^{\circledR}$, and liver stiffness measurement (LSM) using FibroScan ${ }^{\circledR}$ have been validated and compared to biopsy [50,51]. The study was performed on $1289 \mathrm{CHC}$ patients and a 604 healthy volunteer control group. The stage of fibrosis was examined by the three techniques and measurement of ALT was taken as a control test. Based on the results obtained from their analysis, the accuracy of FibroTest and FibroScan ${ }^{\circledR}$ for the diagnosis of advanced fibrosis and cirrhosis in patients with chronic hepatitis $\mathrm{C}$ was confirmed.

Many advantages known for FibroScan ${ }^{\circledR}$ necessitated its modification for overweight patients. It has been reported that XL probe could facilitates liver stiffness measurement (LSM) by transient elastography (TE) in obese patients [51]. They examined the prevalence, risk factors, and causes of discordance between fibrosis estimated by biopsy and the FibroScan ${ }^{\circledR}$ XL probe in 102 patients (BMI) $\geq 28 \mathrm{~kg} / \mathrm{m}^{2}$ ) with chronic liver disease. Their results showed that discordance was 4- to 5-fold more frequent in highly obese patients (BMI $\geq 40 \mathrm{~kg} / \mathrm{m}^{2}: 32 \%$ vs. $8 \%$ ) and liver stiffness above the median of $7.0 \mathrm{kPa}(20 \% v s .4 \%$; both $p<0.0005$ ).

The use of TE for the staging of liver fibrosis has been established in a meta-analysis. The technique was employed for the diagnosis of liver fibrosis due to various factors and to analyze factors influencing the diagnostic accuracy [52-54]. It was reported that age, body mass index, and biopsy quality did not have a significant effect on the area under the receiver operating characteristic curve, AUROC [55]. They reported an excellent diagnostic accuracy of TE for the diagnosis of cirrhosis and progress of fibrosis and that its performance did not depend on underlying liver disease $[56,57]$.

The diagnostic accuracy of transient elastography for diagnosis and staging hepatic fibrosis has been compared to liver biopsy in people with alcoholic liver disease [39]. A number of 834 studies were reviewed to provide data for analyses. In conclusion remarks they have reported that 
summary sensitivity and specificity of transient elastography (seven studies with 330 participants) were 0.95 and 0.71 with LR+ 3.3 and LR-0.07. These results suggested that transient elastography is considered as a useful technique to predict and show the presence of cirrhosis and could open the way to avoid invasive biopsy.

However, increasing prevalence of nonalcoholic fatty liver disease and the importance of viral hepatitis also demand a reliable non-invasive method for screening of liver damage. The benefits and pitfalls of vibration-controlled transient elastography have been reviewed aiming to introduce a framework to interpret its results [58]. The results of their review have revealed that transient elastography can be a reliable technique to show the fibrosis and its progress with about $60-70 \%$ accuracy.

A number of other non-invasive techniques were also introduced during the last few decades and their effectiveness and performances examined and compared to each other and to the liver biopsy. A recent study has compared the diagnostic performances FibroScan ${ }^{\circledR}$ with that of Supersonic Shear Imaging (SSI) for the diagnosis of liver fibrosis in chronic liver disease [59]. In the mentioned study, liver stiffness of 349 consecutive patients with chronic liver diseases who had liver biopsy was assessed by supersonic shear imaging (SSI), Acoustic Radiation Force Impulse (ARFI) imaging and compared to FibroScan ${ }^{\circledR}$ within two weeks of liver biopsy. Their results showed that SSI, Fibro Scan ${ }^{\circledR}$, and ARFI significantly correlated with histological fibrosis score. It was also found that SSI had a higher accuracy than FibroScan ${ }^{\circledR}$ for the diagnosis of severe fibrosis, and a higher accuracy than ARFI for the diagnosis of significant fibrosis. However, they reported that no significant difference was observed for the diagnosis of mild fibrosis and cirrhosis. It was concluded that SSI is an efficient method for the assessment of liver fibrosis in chronic liver diseases, as compared to FibroScan ${ }^{\circledR}$ and ARFI [59].

The accuracy of FibroScan ${ }^{\circledR}$ has also been compared with King's score using liver histology as the reference standard [60]. In this London King's College and the Royal Free Hospital study, liver fibrosis was scored in 187 patients who had undergone a biopsy and diagnosed with chronic hepatitis $\mathrm{C}$ virus (HCV) mono-infection (HCV RNApositive by RT-PCR) using the Ishak method. It was reported that the non-invasive markers and, particularly, FibroScan ${ }^{\circledR}$ were effective tests for the prediction of cirrhosis in chronic hepatitis $\mathrm{C}$
[60]. It is worth reminding that the King's score (KS) is a simple non-invasive test that has been introduced and widely used to predict the prevalence of significant fibrosis or cirrhosis at the bedside or in the clinic.

The accuracy of transient elastography (TE) for the diagnosis of liver fibrosis in patients suffering from Chronic Hepatitis $\mathrm{C}$ (CHC) has been examined in a cohort of consecutive patients with Genotype 1 (G1) CHC [61]. The patients have been assessed by clinical, ultrasonographic and histological (Scheuer score) features. It was found that patients with G1 CHC, the presence of moderate-severe steatosis, detected by histology or by US, should always be taken into account in order to avoid overestimations of liver fibrosis assessed by TE.

Early detection of liver cirrhosis could prevent liver failure and lead the clinician to find the cause and reduce its progress. In order to detect cirrhosis, in early stages by a non-invasive method, the use of transient elastography (TE) for the detection of cirrhosis and oesophageal varices (OV) in chronic hepatitis $\mathrm{C}(\mathrm{CHC})$ has been reported $[62,63]$. The accuracy of $\mathrm{CE}$ is compared with other noninvasive methods including AST/ALT ratio (AAR), APRI, prothrombin index (PI), platelet count (PC) and FibroTest ${ }^{\mathrm{TM}}$ (FT). The gld standard, liver biopsy (LB), has been used as reference, in 298 consecutive CHC patients. According to the report from that study, TE had the best diagnostic accuracy for detection of cirrhosis (AUROCs: TE 0.96 vs. FT 0.82 , Lok and APRT 0.80, PC 0.79, PI 0.73, AAR 0.61 . On the other hand, the percentage of saved LB was found to be: TE (cut-off: $12.5 \mathrm{kPa}$ ) $90 \%$, PC $82 \%$, FT 79\%, PI 77\%, AAR 76\%, APRI 70\%, and Lok $45 \%$, respectively.

Steatosis, the most common consequence of fibrosis, should also be controlled and assessed with care. Controlled attenuation parameter (CAP) evaluated with transient elastography (FibroScan ${ }^{\circledR}$ ) is a recent method for non-invasive assessment of steatosis. As the usefulness of the method in clinical practice has been unknown, a prospective based study investigated the determinants of CAP failure and the relationships between CAP and clinical or biological parameters. The study was performed in a large cohort of consecutive adult patients with suspected chronic liver disease [55, 64]. In these research works, the possible influence of some variants including age, gender, body mass index, waist circumference, hypertension, diabetes, metabolic syndrome and alcohol use, liver stiffness measurements have been analyzed for their influence 
on CAP value. The results of multivariate analysis indicated that factors independently associated with CAP measurement failure were female gender, BMI, and metabolic syndrome. However, the same type of analysis showed that factors significantly associated with elevated CAP were BMI (2530) $\mathrm{kg} / \mathrm{m}^{2}$, BMI $>30 \mathrm{~kg} / \mathrm{m}^{2}$, metabolic syndrome, alcohol $>14$ drink/week and liver stiffness $>6 \mathrm{kPa}$. They concluded that CAP could provide an immediate assessment of steatosis simultaneously with liver stiffness measurement. It has been suggested that the strong association of CAP with the metabolic syndrome and alcohol use could be of interest for the follow-up of NAFLD or alcoholic patients [65].

It is a well-known fact that one of the most common results of injury to the liver is hepatic fibrogenesis, a critical factor leading to hepatic dysfunction and it may be important in the pathogenesis of portal hypertension.

A new bidimensional elastography technique, supersonic shear imaging (SSI), has been used to evaluate liver fibrosis in 113 patients with $\mathrm{HCV}$ infection and compared with FibroScan ${ }^{\circledR}$ [66]. According to the results SSI appears as a fast, simple and reliable method for non-invasive liver fibrosis evaluation.

A review in 2012 has reported recent findings on non-invasive alternatives for the diagnosis of fibrosis and cirrhosis in patients who are coinfected with HIV and HCV [67]. By analyzing data obtained from literature, they have summarized that serum biomarkers as well as transient elastography can accurately diagnose fibrosis and cirrhosis and are better at excluding than at predicting liver disease in $\mathrm{HIV} / \mathrm{HCV}$-coinfected patients.

Using a combination of various non-invasive tests for staging liver fibrosis could improve diagnostic accuracy. This was examined in the case of $116 \mathrm{HIV} / \mathrm{HCV}$ coinfected patients [68]. In this study, the validity of transient elastography (TE), Fibrotest (FT), the aspartate aminotransferase-toplatelet ratio index (APRI) were compared. It was found that in $\mathrm{HIV} / \mathrm{HCV}$-coinfected patients, TE and FT had a similar diagnostic accuracy for significant fibrosis, whereas TE had the best accuracy for cirrhosis.

In a similar study the effectiveness of the novel FibroScan ${ }^{\circledR}$ was compared to measurement of serum indices as alternatives to liver biopsy in HIV/hepatitis C virus (HCV)-coinfected patients [69]. Their results concluded that transient elastography accurately predicted liver fibrosis as compared to other simple non-invasive indexes in $\mathrm{HIV} / \mathrm{HCV}$ - coinfected patients. It was, therefore, suggested that TE could be a rapid, accurate and helpful tool for guiding therapeutic decisions in clinical practice.

\section{CONCLUSIONS}

Liver fibrosis, characterized by excessive deposition of extracellular matrix, occurs in various conditions including chronic alcohol consumption, hepatitis virus, nonalcoholic steatohepatitis and genetic disorders.

It is initiated when chronic liver injury stimulates production of mediators by hepatocytes, bile duct epithelial cells, platelets, kupffer cells, and other inflammatory cells. They, therefore, cause cells in the liver to differentiate into myofibroblasts. Myofibroblasts originate from hepatic stellate cells (HSCs), peribiliary fibroblasts, hepatocytes, bile duct epithelial cells, and bone marrow-derived cells. Growth factors are produced during the genesis of this disease that stimulates myofibroblast proliferation, and chemokines are produced that stimulate these cells to migrate to injured regions of the liver. Once the myofibroblasts accumulate in these regions, they are stimulated to produce collagen and other components of extracellular matrix causing fibrosis.

While the mechanism of fibrosis has been identified, there are almost no therapies currently available that directly prevent or reverse fibrosis. Therefore, further studies are needed to identify new and effective therapeutic targets to treat this disease.

Explaining the underlying mechanism of fibrogenesis, in this review article, the advantages and pitfalls of various non-invasive methods for diagnosis and staging liver fibrosis, including vibration-controlled transient elastography, were studied.

Early detection and staging of fibrosis could help reduce the danger and prevent its development to cirrhosis. Liver biopsy is known as the gold standard for diagnosis and detection of fibrosis as well as staging its progress. However, the method is invasive, expensive and hardly accepted by patients. Most of the new non-invasive methods depend on either 'biological' or 'physical' approaches.

Vibration-controlled transient elastography, commonly delivered by the FibroScan device, is a new and novel technique recently approved by the Food and Drug Administration for the noninvasive assessment of liver disease. Transient elastography 
(TE) is currently the most accurate non-invasive method for early detection of cirrhosis in $\mathrm{CHC}$ as compared with other available methods, but it cannot replace endoscopy for OV screening.

TE is a simple, reliable, painless, rapid and useful method for assessing liver fibrosis in primary biliary cirrhosis. It has excellent patient acceptance and is useful for monitoring fibrosis progression and regression in the individual case.
It is also concluded that SSI is an efficient method for the assessment of liver fibrosis in chronic liver diseases, comparing favourably to FibroScan ${ }^{\circledR}$ and ARFI.

On the other hand, the combined use of FibroScan ${ }^{\circledR}$ and FibroTest to evaluate liver fibrosis could avoid a biopsy procedure in most patients.

Conflict of interest: The author confirms that he had no conflict of interest.

Fibrogeneza hepatică este rezultatul final al leziunii hepatice. Fibroza duce la disfuncție hepatică ce determină alte comorbidități. Înțelegerea aşadar a mecanismelor fibrogenetice, realizarea unui diagnostic corect încă din stadiile timpurii duce la scăderea prevalenței cirozei hepatice. Strategiile terapeutice şi metodele de detecție depind de progresia fibrozei hepatice şi de rata dezvoltării cirozei. Tradițional, standardul de aur pentru evaluarea cirozei hepatice este puncția, biopsia hepatică, o manvera invazivă. În ultimul timp însă au fost dezvoltate mai multe metode non-invazive pentru a putea evalua mai uşor fibroza hepatică. Inițial aceste metode au fost dezvoltate pentru pacienții cu hepatită cronică cu virus hepatitic $C$. Astfel că necesitatea biopsiei a scăzut foarte mult în ultima vreme.

In acest articol tip review sunt trecute în revistă principalele mecanisme fibrogenetice, diagnosticul fibrozei hepatice, strategiile pentru evaluarea şi tratamentul fibrozei hepatice.

\author{
Correspondence to: Ali Erfani Karimzadeh Toosi, Shahid Beheshti University Hospital \\ Guilan University of Medical Sciences, Gilan, Iran \\ Tel: 00981333764796 \\ Email: alierfani2002@yahoo.com
}

\title{
ABBREVIATIONS
}

$\begin{array}{llll}\text { AE2 } & \text { Anion exchanger 2 } & \text { EMT } & \text { Epithelial-mesenchymal transition } \\ \text { AIP } & \text { Autoimmune pancreatitis } & \text { ERCP } & \text { Endoscopic retrograde cholangio-pancreaticography } \\ \text { ALP } & \text { Alkaline phosphatase } & \text { ETM } & \text { Epithelial-mesenchymal transition } \\ \text { ALT } & \text { Alanine aminotransferase; } & \text { FGF-2 } & \text { Fibroblast growth factor-2 } \\ \text { AMAs } & \text { Antimitochondrial antibodies } & \text { FLI } & \text { Fatty liver index } \\ \text { ANIT } & \text { Alpha-naphthylisothiocyanate } & \text { FT } & \text { FibroTest }{ }^{\circ} \\ \text { APRI } & \text { Aspartate-to-Platelet Ratio Index } & \text { G1 } & \text { Genotype 1 } \\ \text { ARFI } & \text { Acoustic Radiation Force Impulse } & \text { GFAP } & \text { Glial fibrillary acidic protein } \\ \text { AST } & \text { Aspartate AminoTransferase } & \text { GGT } & \text { Gamma-Glutamyl Transpeptidase } \\ \text { AST/ALT Aspartate aminotransferase/alanine aminotransferase } & \text { Gnt-V } & \text { N-acetyl glucosaminyltransferase V } \\ & \text { ratio index } & \text { HBV } & \text { Hepatitis B virus } \\ \text { AUROC } & \text { Area under the receiver operating charac-teristic curve } & \text { HCC } & \text { Hepatocellular carcinomas } \\ \text { BMI } & \text { Body mass index } & \text { HCV } & \text { Hepatitis C virus } \\ \text { CAP } & \text { Controlled attenuation parameter } & \text { HD } & \text { Hemodialysis } \\ \text { CFTR } & \text { Cystic fibrosis transmembrane conductance regulator } & \text { HGF } & \text { Hepatocyte growth factor } \\ \text { CHB } & \text { Chronic hepatitis B } & \text { HSC } & \text { Hepatic stellate cells } \\ \text { CHC } & \text { Chronic hepatitis C } & \text { IGF1 } & \text { Insulin-like growth factor 1 } \\ \text { CI } & \text { Confidence interval } & \text { ILK } & \text { Integrin-linked kinase } \\ \text { CLDs } & \text { Chronic liver diseases } & \text { IQR } & \text { Interquartile range } \\ \text { CRBP } & \text { Cellular retinol-binding proteins } & \text { KO } & \text { Knockout } \\ \text { CRC } & \text { Colorectal cancer } & \text { kPa } & \text { Kilopascal } \\ \text { CTGF } & \text { Connective tissue growth factor } & \text { KS } & \text { King's score } \\ \text { DCC } & 3.5 \text {-diethoxycarbonyl-1.4-dihydrocollidine } & \text { LB } & \text { Liver biopsy } \\ \text { ECM } & \text { Extracellular matrix } & \text { LRAT } & \text { Lecithin-retinol acyltransferase }\end{array}$




$\begin{array}{llll}\text { LSM } & \text { Liver Stiffness Measurement } & \text { PPV } & \text { Positive predictive value; } \\ \text { LXR } & \text { Liver X receptor } & \text { PSC } & \text { Primary sclerosing cholangitis } \\ \text { MCP-1 } & \text { Monocyte chemoattractant protein-1 } & \text { PT } & \text { Prothrombin time } \\ \text { MFs } & \text { Myofibroblasts } & \text { RI } & \text { Ribonuclease inhibitor } \\ \text { MRCP } & \text { Magnetic resonance cholangio-pancreaticography } & \text { ROI } & \text { Region of interest } \\ \text { NAFLD } & \text { Nonalcoholic fatty liver disease } & \text { SF } & \text { Significant fibrosis } \\ \text { NASH } & \text { Nonalcoholic steatohepatitis } & \text { SSI } & \text { Supersonic shear imaging } \\ \text { NGF } & \text { Nerve growth factor } & \text { STAP } & \text { Stellate cell activation-associated protein } \\ \text { NPV } & \text { Negative predictive value } & \text { TE } & \text { Transient elastography } \\ \text { OR } & \text { Odds ratio } & \text { TGF } \beta & \text { Transforming growth factor } \beta \\ \text { pANCA } & \text { Perinuclear antineutrophil cytoplasmatic antibody } & \text { UDCA } & \text { Ursodeoxycholic acid } \\ \text { PBC } & \text { Primary biliary cirrhosis } & \text { US } & \text { Ultrasonography } \\ \text { PDC-E2 } & \text { E2 subunit of pyruvate dehydrogenase complex } & \text { VCTE } & \text { Vibration-controlled transient elastography } \\ \text { PDGF } & \text { Platelet-derived growth factor } & \text { VDR } & \text { Farnesoid X receptor (FXR), vitamin D receptor } \\ \text { PPAR } \gamma & \text { Peroxisome proliferator activated receptor } \gamma & \text { VEGF } & \text { Vascular endothelial growth factor }\end{array}$

\section{REFERENCES}

1. KOH C, HELLER T. Approach to the diagnosis of portal hypertension. THEO HELLER 2012; 1(5): 133-135.

2. FLOREANI A, CAZZAGON N, MARTINES D, CAVALLETTO L, BALDO V, CHEMELLO L. Performance and utility of transient elastography and noninvasive markers of liver fibrosis in primary biliary cirrhosis. Digestive and Liver Disease, Liver, Pancreas and Biliary Tract 2011; 43(11): 887-892.

3. POUPON R, CORPECHOT C. Elastography-based assessment of primary biliary cirrhosis staging. Digestive and Liver Disease 2011; 3(11): 839-840.

4. CASTERA L. Invasive and non-invasive methods for the assessment of fibrosis and disease progression in chronic liver disease. Best Practice \& Research Clinical Gastroenterology 2011; 25(2): 291-303.

5. CASTERA L, FORNS X, ALBERTI A, et al. Non-invasive evaluation of liver fibrosis using transient elastography. Journal of Hepatology 2008; 48(5): 835-847.

6. ROCKEY DC. Noninvasive assessment of liver fibrosis and portal hypertension with transient elastography. Gastroenterology 2008; 134(1): 8-11.

7. FORBES SJ, PAROLA M. Liver fibrogenic cells. Best Practice \& Research Clinical Gastroenterology 2011; 25(2): $207-217$.

8. LEE JS, SEMELA D, IREDALE J, SHAH VH. Sinusoidal remodeling and angiogenesis: a new function for the liver-specific pericyte? Hepatology 2007; 45: 817-825.

9. YANG JD, NAKAMURA I, ROBERTS LR. The tumor microenvironment in hepatocellular carcinoma: Current status and therapeutic targets. Semin Cancer Biol 2012; 21: 35-43.

10. ZHAO W, ZHANG L, YIN Z, SU W, REN G, ZHOU C, YOU J, FAN J, WANG X. Activated hepatic stellate cells promote hepatocellular carcinoma development in immunocompetent mice. Int J Cancer 2011; 129: 2651-2561.

11. KANG N, YAQOOB U, GENG Z, BLOCH K, LIU C, GOMEZ T, BILLADEAU D, et al. Focal adhesion assembly in myofibroblasts fosters a microenvironment that promotes tumor growth. Am J Pathol 2010; 177: 1888-1900.

12. AMANN T, BATAILlE F, SPRUSS T, MUHLBAUER M, GABELE E, SCHOLMERICH J, KIEFER P, et al. Activated hepatic stellate cells promote tumorigenicity of hepatocellular carcinoma. Cancer Sci 2009; 100: 646-653.

13. SANCHO-BRU P, JUEZ E, MORENO M, KHURDAYAN V, MORALES-RUIZ M, COLMENERO J, ARROYO V, et al. Hepatocarcinoma cells stimulate the growth, migration and expression of pro-angiogenic genes in human hepatic stellate cells. Liver International 2010; 30: 31-41.

14. GUO HB, RANDOLPH M, PIERCE M. Inhibition of a specific N-glycosylation activity results in attenuation of breast carcinoma cell invasiveness-related phenotypes: Inhibition of epidermal growth factor-induced dephosphorylation of focal adhesion kinase. J Biol Chem 2007; 282: 22150-22162.

15. SCHLUGER LK, SHEINER PA, THUNG SN, LAU JY, MIN A, WOLF DC, FIEL I, et al. Severe recurrent cholestatic hepatitis $C$ following orthotopic liver transplantation. Hepatology 1996; 23: 971-976.

16. BONNARD P, LESCURE FX, AMIEL C, GUILARD SCHMIDT JB, CALLARD P, GHARAKHANIAN S, et al. Documented rapid course of hepatic fibrosis between two biopsies in patients coinfected by HIV and HCV despite high CD4 cell count. J Viral Hepat 2007; 14: 806-811.

17. DEV A, PATEL K, CONRAD A, BLATTE LM, MC HUTCHISON JG. Relationship of smoking and fibrosis in patients with chronic hepatitis $C$. Clin Gastroenterol Hepatol 2006; 4: 797-801.

18. LIU J, ZHANG Z, TU X, LIU J, ZHANG H, ZHANG J, ZANG Y, et al. Knockdown of N-acetylglucosaminyl transferase V ameliorates hepatotoxin-induced liver fibrosis in mice. Toxicol Sci 2013; 135(1): 144-155.

19. MIAO CG, YANG YY, HE X, HUANG C, HUANG Y, ZHANG L, LV XW, JIN Y, LI J. Wnt signaling in liver fibrosis: progress, challenges and potential directions. Biochimie 2013; 95(12): 2326-2335.

20. HAZRA S, XIONG S, WANG J, RIPPE RA, KRISHNA V, CHATTERJEE K, TSUKAMOTO H. Peroxisome proliferatoractivated receptor gamma induces a phenotypic switch from activated to quiescent hepatic stellate cells. J Biol Chem 2004; 279: 11392-11401.

21. SHE H, XIONG S, HAZRA S, TSUKAMOTO H. Adipogenic transcriptional regulation of hepatic stellate cells. J Biol Chem 2005; 280: 4959-4967. 
22. ZENG G, AWAN F, OTRUBA W, MULLER P, APTE U, TAN X, GANDHI C, et al. Wnt'er in liver: expression of Wnt and frizzled genes in mouse. Hepatology 2007; 45: 195-204.

23. LEMAIGRE FP. Mechanisms of liver development: concepts for understanding liver disorders and design of novel therapies. Gastroenterology 2009, 137, 1, 62-79.

24. THIERY JP. Epithelial-mesenchymal transitions in development and pathologies. Curr Opin Cell Biol 2003; 15(6): 740-746.

25. MEDICI D, NAWSHAD A. Type I collagen promotes epithelial-mesenchymal transition through ILK-dependent activation of $N F-\kappa B$ and LEF-1. Matrix Biol 2010; 29(3):161-165.

26. SHINTANI Y, MAEDA M, CHAIKA N, JOHNSON KR, WHEELOCK MJ. Collagen I promotes epithelial-to-mesenchymal transition in lung cancer cells via transforming growth factor- $\beta$ signaling. Am J Respir Cell Mol Biol 2008; 38: 95-104.

27. ZHOU BP, DENG J, XIA W, XU J, LI YM, GUNDUZ M, HUNG MC. Dual regulation of Snail by GSK-3beta-mediated phosphorylation in control of epithelial-mesenchymal transition. Nat Cell Biol 2004; 6: 931-940.

28. LIANG F, ZHANG S, WANG B, QIU J, WANG Y. Overexpression of integrin-linked kinase (ILK) promotes glioma cell invasion and migration and down-regulates E-cadherin via the NF- $\kappa B$ pathway. J Mol Histol 2014; 45(2): 141-51.

29. XIONG D, LIOU Y, SHU J, LI D, ZHANG L, CHEN J. Down-regulating ribonuclease inhibitor enhances metastasis of bladder cancer cells through regulating epithelial-mesenchymal transition and ILK signaling pathway. Exp Mol Pathol 2014; 96(3): 411-421.

30. YAN Z, YIN H, WANG R, WU D, LIU B, SU Q. Overexpression of integrin-linked kinase (ILK) promotes migration and invasion of colorectal cancer cells by inducing epithelial-mesenchymal transition via $N F-\kappa B$ signaling. Acta Histochem 2014; 116(3): 527-33.

31. BATALLER R, ROMBOUTS K, ALTAMIRANO J, MARRA F. Fibrosis in alcoholic and nonalcoholic steatohepatitis. Best Practice \& Research Clinical Gastroenterology 2011; 25(2): 231-244.

32. SCHUPPAN D, KREBS A, BAUER M, HAHN EG. Hepatitis $C$ and liver fibrosis. Cell Death Differ 2003: 10 (Suppl 1): S59-67.

33. HASELTINE EL, PENNEY MS, GEORGE S, KIEFFER TL. Successful treatment with telaprevir-based regimens for chronic hepatitis $C$ results in significant improvements to serum markers of liver fibrosis. J Viral Hepat 2015, ahead of print.

34. FLISIAK R. Chance of hepatic fibrosis treatment in chronic hepatitis $C$ (in Polish). Przegl Epidemiol 2004; 58(Suppl 1): $76-79$.

35. LUGO-BARUQUI A, BAUTISTA LÓPEZ CA, Armendáriz-Borunda J. Novel treatments for hepatitis $C$ viral infection and the hepatic fibrosis. Article in Spanish. Rev Med Chil 2009; 137(2): 280-288.

36. PENZ-ÖSTERREICHER M, ÖSTERREICHER CH, TRAUNER M. Fibrosis in Autoimmune and Cholestatic Liver Disease. Best Practice \& Research Clinical Gastroenterology 2011; 25(2): 245-258.

37. ALISI A, DE VITO R, MONTI L, NOBILI V. Liver fibrosis in paediatric liver diseases. Best Practice \& Research Clinical Gastroenterology 2011; 25(2): 259-268.

38. PINZANI M, ROSSELLI M, ZUCKERMANN M. Liver Cirrhosis. Best Practice \& Research Clinical Gastroenterology 2011; 25(2): 281-290.

39. PAVLOV CS, CASAZZA G, NIKOLOVA D, TSOCHATZIS E, BURROUGHS AK, IVASHKIN VT, GLUUD C. Transient elastography for diagnosis of stages of hepatic fibrosis and cirrhosis in people with alcoholic liver disease. Cochrane Database Syst Rev 2015; 22; 1:CD010542. [Epub ahead of print]

40. VERGNIOL J, FOUCHER J, TERREBONNE E, BERNARD PH, LE BAIL B, MERROUCHE W, COUZIGOU P, et al. Noninvasive tests for fibrosis and liver stiffness predict 5-year outcomes of patients with chronic hepatitis C. Gastroenterology 2011; 140(7): 1970-1979.

41. SCHIAVON LL, SCHIAVON JLN, CARVALHO-FILHO RJ. Noninvasive means of diagnosing liver fibrosis in hepatitis C. World J Gastroenterol 2014; 20(11): 2854-2866.

42. LIN ZH, XIN YN, DONG QJ, WANG Q, JIANG XJ, ZHAN SH, SUN Y, et al. Performance of the aspartate aminotransferase-to-platelet ratio index for the staging of hepatitis C-related fibrosis: an updated meta-analysis. Hepatology 2011; 53(3): 726-736.

43. KAYADIBI H, YASAR B, OZKARA S, SERDAR MA, KURDAS OO, GONEN C. The diagnostic accuracy of the Forns index, platelet count and AST to Platelet Ratio Index derived fibrosis index for the prediction of Hepatitis $C$ virus-related significant liver fibrosis and cirrhosis. Scand J Clin Lab Invest 2014; 74(3): 240-247.

44. HOLMBERG SD, LU M, RUPP LB, LAMERATO LE, MOORMAN AC, VIJAYADEVA V, BOSCARINO JA, et al. Noninvasive serum fibrosis markers for screening and staging chronic hepatitis $C$ virus patients in a large US cohort. Clin Infect Dis 2013; 57(2): 240-246.

45. PAUNOVIC K, STOJANOVIC M, DIMITRIJEVIC Z, PAUNOVIC G, DJORDJEVIC V, KONSTANTINOVIC L, KOSTIC S. Indirect serum fibrosis markers in hepatitis C virus (HCV) infection. Med Arch 2012; 66(4): 226-230.

46. SHAHEEN AA, MYERS RP. Diagnostic accuracy of the aspartate aminotransferase-to-platelet ratio index for the prediction of hepatitis C-related fibrosis: a systematic review. Hepatology 2007; 46(3): 912-921.

47. XIAO G, YANG J, YAN L. Comparison of diagnostic accuracy of aspartate aminotransferase to platelet ratio index and fibrosis-4 index for detecting liver fibrosis in adult patients with chronic hepatitis $B$ virus infection: A systemic review and metaanalysis. Hepatology 2015; 61(1): 292-302.

48. NGUYEN K, PAN C, XIA V, HU J, HU KQ. Clinical course of chronic hepatitis B (CHB) presented with normal ALT in Asian American patients. J Viral Hepat 2015 Jan 22 [Epub ahead of print].

49. XU XY, KONG H, SONG RX, ZHAI YH, WU XF, AI WS, LIU HB. The effectiveness of noninvasive biomarkers to predict hepatitis B-related significant fibrosis and cirrhosis: a systematic review and meta-analysis of diagnostic test accuracy. PLoS One 2014; 9(6): e100182.

50. POYNARD T, DE LEDINGHEN V, ZARSKI JP, STANCIU C, MUNTEANU M, VERGNIOL J, FRANCE J, et al. Relative performances of FibroTest, FibroScan ${ }^{\circledR}$, and biopsy for the assessment of the stage of liver fibrosis in patients with chronic hepatitis C: A step toward the truth in the absence of a gold standard. Journal of Hepatology 2012; 56: 541-548. 
51. MYERS RP, LAYRARGUES GP, KIRSCH R, POLLETT A, BEATON M, LEVSTIK M, DUARTE-ROJO A, et al. Discordance in fibrosis staging between liver biopsy and transient elastography using the FibroScan ${ }^{\circledR} X L$ probe. Journal of Hepatology 2012; 56(3): 564-570.

52. PATEL J, PARIKH P, BHATE P, CHOKSEY A, KHOT A, INGLE M, SAWANT P. Correlation of Liver Stiffness Measurement by FibroScan $\AA$ in Alcoholic Liver Disease and Hepatitis B Related Chronic Liver Disease. Journal of Clinical and Experimental Hepatology 2014; 4(2): S74-S79.

53. ROUND AM, NAP-HILL E, TAKACH O, LAM EC, KO HH, RAMJI A. Fibrosis Regression in Persons Treated for HBV Utilizing Transient Elastography (FibroScan $\left.{ }^{\circledR}\right)$. Gastroenterology 2014; 146(5): S-961-S-962.

54. CORPECHOT C, GAOUAR F, EL NAGGAR A, KEMGANG A, WENDUM D, POUPON R, CARRAT F, et al. Liver stiffness assessed by FibroScan ${ }^{\circledR}$ is a major prognostic factor in primary sclerosing choangitis. Journal of Hepatology 2014; 60(1): S34-S44.

55. ERFANI KARIMZADEH TOOSI A. Investigating the severity of liver fibrosis by transient elastography (FibroScan $\left.{ }^{\circledR}\right)$ in patients receiving methotrexate. A thesis submitted as partial fulfillment for degree of Subspeciality in Adult Gastroenterology and Hepatology. Guilan University of Medical Sciences Dec 2013.

56. MIREEN FRIEDRICH-RUST, MEI-FANG ONG, SWANTJE MARTENS, et al. Performance of Transient Elastography for the Staging of Liver Fibrosis: A Meta-Analysis. Gastroenterology 2008; 134(4): 960-974.

57. TALWALKAR JA, KURTZ DM, SCHOENLEBER SJ, et al. Ultrasound-Based Transient Elastography for the Detection of Hepatic Fibrosis: Systematic Review and Meta-analysis. Clinical Gastroenterology and Hepatology 2007; 5(10): 1214-1220.

58. TAPPER EB, CASTERA L, AFDHAL NH. FibroScan ${ }^{\circledR}$ (Vibration-Controlled Transient Elastography): Where Does It Stand in the United States Practice. Clinical Gastroenterology and Hepatology 2015; 13(1): 27-36.

59. CASSINOTT C, LAPUYADE B, MOURIES A, HIRIART JB, VERGNIOL J, GAYE D, CASTAIN C, et al. Non-invasive assessment of liver fibrosis with impulse elastography: Comparison of Supersonic Shear Imaging with ARFI and FibroScan ${ }^{\circledR}$. Journal of Hepatology 2014; 61(3): 550-557.

60. CROSS TJS, CALVARUSO V, MAIMONE S, CAREY I, CHANG TP, PLEGUEZUELO M, et al. Prospective comparison of

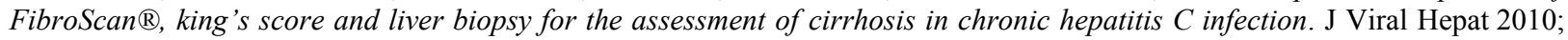
17(8): 546-554.

61. MACALUSO FS, MAIDA M, CAMMÀ C, CABIBBO G, CABIBI D, ALDUINO R, DI MARCO V, et al. Steatosis affects the performance of liver stiffness measurement for fibrosis assessment in patients with genotype 1 chronic hepatitis $C$. Journal of Hepatology 2014; 61(3): 523-529.

62. CASTÉRA L, LE BAIL, ROUDOT-THORAVAL F, BERNARD PH, FOUCHER J, MERROUCHE W, COUZIGOU P, et al. Early detection in routine clinical practice of cirrhosis and oesophageal varices in chronic hepatitis C: Comparison of transient elastography (FibroScan $\left.{ }^{\circledR}\right)$ with standard laboratory tests and non-invasive scores. Journal of Hepatology 2009; 50(1): 59-68.

63. BOSCH J. Towards the non-invasive diagnosis of cirrhosis: The nuts-cirrhosis connection. Journal of Hepatology 2009; 50(1): 4-6.

64. VICTOR DE LÉDINGHEN, JULIEN VERGNIOL, MAYLIS CAPDEPONT, et al. Controlled attenuation parameter (CAP) for the diagnosis of steatosis: A prospective study of 5323 examinations. Journal of Hepatology 2014; 60(5): 1026-1031.

65. BERZIGOTTI A. Getting closer to a point-of-care diagnostic assessment in patients with chronic liver disease: Controlled attenuation parameter for steatosis. Journal of Hepatology 2014; 60(5): 910-912.

66. BAVU E, GENNISSON JL, COUADE M, BERCOFF J, MALLET V, FINK M, BADEL A, et al. Non-invasive in vivo liver fibrosis evaluation using supersonic shear imaging: a clinical study on 113 hepatitis $C$ virus patients. Ultrasound Med Biol 2011; 37(9): 1361-1373.

67. RESINO S, SÁNCHEZ-CONDE M, BERENGUER J. Coinfection by human immunodeficiency virus and hepatitis $C$ virus: non-invasive assessment and staging of fibrosis. Curr Opin Infect Dis 2012; 25(5): 564-9.

68. CASTERA L, WINNOCK M, PAMBRUN E, PARADIS V, PEREZ P,LOKO MA, ASSELINEAU J, et al. Comparison of

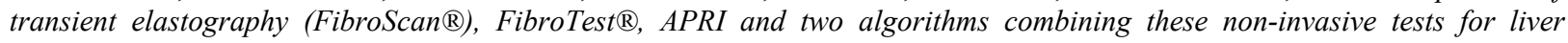
fibrosis staging in HIV/HCV coinfected patients: ANRS CO13 HEPAVIH and FIBROSTIC collaboration. HIV Med 2014; 15(1): $30-9$.

69. SÁNCHEZ-CONDE M, MONTES-RAMÍREZ ML, MIRALLES P, ALVAREZ JM, BELLÓN JM, RAMÍREZ M, ARRIBAS $\mathrm{JR}$, et al. Comparison of transient elastography and liver biopsy for the assessment of liver fibrosis in HIV/hepatitis $C$ viruscoinfected patients and correlation with non-invasive serum markers. J Viral Hepat 2010; 17(4): 280-6.

Received May 5, 2015 